\title{
Evaluation of In vitro Antioxidant Activity of Nelumbo nucifera Leaf Extract and its Potential Application as Antibacterial Agent against Fish Pathogens
}

\author{
Mudasir Maqsood Hakim ${ }^{*}$, Nazir Ahmad Ganai ${ }^{2}$, Syed Mudasir Ahmad ${ }^{1}$, Oyas Ahmad \\ Asimi $^{3}$, Tariq Raja ${ }^{2}$, Feroz Ahmad Shah ${ }^{4}$, Jalal-ul-Din Parrah ${ }^{5}$ and Riaz Ahmad Shah ${ }^{1}$ \\ ${ }^{1}$ Division of Animal Biotechnology, Faculty of Veterinary Sciences \& Animal Husbandry, \\ SKUAST-Kashmir, India \\ ${ }^{2}$ Division of Animal Genetics and Breeding, Faculty of Veterinary Sciences \& Animal \\ Husbandry, SKUAST-Kashmir, India \\ ${ }^{3}$ Division of Fish Nutrition and Biochemistry, Faculty of Fisheries, SKUAST-Kashmir, India \\ ${ }^{4}$ Division of Aquatic Animal Health \& Management, Faculty of Fisheries, \\ SKUAST-Kashmir, India \\ ${ }^{5}$ Mountain Livestock Research Institute, SKAUST-Kashmir, India \\ *Corresponding author
}

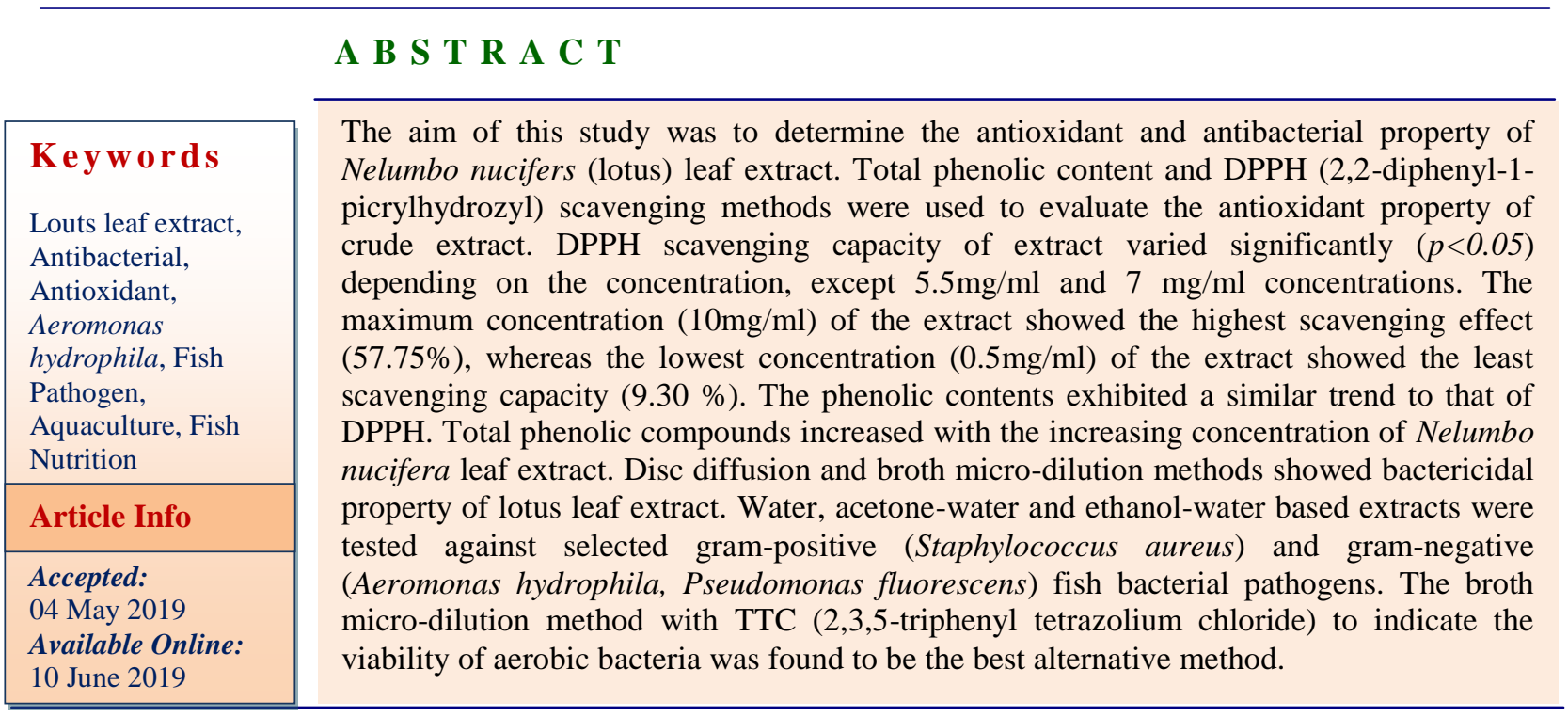

\section{Introduction}

Resistance of microorganisms to existing antibiotics is evolving and there is an escalating requirement for new antibiotics not only in human but also in veterinary medicine. Antimicrobial defence strategies have evolved in aquatic ecosystem in 
response to competition for space and nutrients. Therefore, aquatic plants, offer a rich source of prospective new drugs. Nelumbo nucifera (Family: Nelumbonaceae) commonly known as lotus or sacred lotus is an aquatic perennial plant. The plant grows up to a height of about 1.5 meters and a spreads horizontally up to 3 meters. Lotus plant remains embedded in mud of the water body. Leaves measuring approximately $60 \mathrm{~cm}$ in diameter, arise directly from the rhizome and can either be floating on the water or raised 30 to $46 \mathrm{~cm}$ ( 1 to $1.5 \mathrm{ft}$ ) above the water. The floral part arising from stem above leaves, grows up to $20 \mathrm{~cm}$ in diameter. Seeds and rhizome are used for propagating the plant (Sayre, 2004) Plant has been used in conventional therapies for a long time and finds it relevance in both human and veterinary medicine. There are ample reports of the plant being used in different medical conditions (anti-diabetic, anti-cancer, antidepressant, anti-inflammatory, anti-bacterial, anti-oxidant, immunomodulatory, and antiviral etc) (Sheikh, 2014). There are studies of lotus extracts being used to treat cancer, tissue inflammation, antiemetic, obesity and skin diseases (Ling et al., 2005; Liu et al., 2015; Mehta et al., 2013; Ono et al., 2006). However, the use of Nelumbo nucifera in veterinary medicine is new and no such studies are available for aquaculture species.

Aquaculture production has witnessed a remarkable increase since last decade. Increasing demand for animal protein has made fish culture vulnerable on many levels. Increasing mortality due to disease incidence is the prime cause of low productivity, which ultimately affects the income (Figueiredo et al., 2006, Hatha et al., 2005). Fish are susceptible to a number of bacterial infections, primarily when stocked in high densities. In order to prevent the disease outbreak, antibiotics are used as one of the prophylactic measures. However, indiscriminate use of such disease management practices exposes the fish to a range of potential problems. Evolving resistance is one of the major concerns of using antibiotics in aquaculture. The practice not only puts fish species at risk but also becomes a potential source of resistance development in other animal and human pathogens (Serrano, 2005). Some bacterial fish pathogens are also associated to human diseases, making the aquaculture products a likely risk to the consumer's health (Yanong and Francis-Floyd, 2006).

Aeromonas hydrophila is responsible for cases of skin infections, septicemia and gastroenteritis in fish and human ( $\mathrm{Yu}$ et al., 2007). This bacterium causes haemorrhagic septicaemia, infectious abdominal dropsy in a verity of fish species and has been observed occasionally in marine fish species, amphibians, reptiles, cattle and humans throughout the world (Bullock et al., 1971; Egusa, 1978; Schäperclaus et al., 1992); Khardori and Fainstein, 1988). The bacterium is distributed widely in fresh water and bottom sediments containing organic material, as well as in the intestinal tract of fish (Egusa, 1978; Hazen et al., 1978). Aeromonas hydrophila is typically recognised as an opportunistic pathogen or secondary invader (Austin and Austin, 1987). Conversely, there have been reports of $A$. hydrophila acting as a primary pathogen in fish. Isolates differ greatly in their pathogenicity with some strains being highly virulent and others nonvirulent. Most cultured and wild freshwater fish species are susceptible to Aeromonas hydrophila infection. However, cold-water fish, including brown trout (Salmo trutta), and rainbow trout (Oncorhynchus mykiss) are more prone to diseases due to this bacterial pathogen (Bullock et al., 1971; Egusa, 1978).

Pseudomonas fluorescens is a common gramnegative, rod-shaped bacterium, recognised as one of the bacterial species that are frequently associated with fish diseases (Bullock, 1964). 
Pseudomonas infection in fish leads to the development of haemorrhagic septicaemia, so-called red skin disease, a condition called pseudomonasis, which occur throughout the year particularly when fish is in stress either because of inappropriate handling or during transportation. The prevailing lacunae in terms of disease management often lead to higher mortality, resulting in economic losses. Staphylococcus aureus is a gram-positive round shaped bacteria affecting various aquaculture fish species globally. The affected fishes exhibit distended abdomen, erratic swimming, melanosis, exophthalmia, haemorrhages, peri-anal edema, similar to the symptom by Edwardsiella tarda infection (Lin et al., 2007; Pressley et al., 2005).

Although, there are policies devised by Food and Agricultural Organisation (FAO) and other regulatory authorities to check the indiscriminate use of antibiotics in aquaculture.

In order to address the problems of microbial resistance in a more responsible way, there is an urgent need to find alternatives; the discovery of new phyto-chemicals and unconventional therapies to control bacterial diseases is one of the promising areas to explore.

Owing the ability to synthesise many different compounds, the plants are one of the potential sources of new drugs (Antunes et al., 2006, Cowan, 1999). The aim of this study was to find out the in vitro antioxidant activity and antibacterial activity of leaf extract of Nelumbo nucifera (NNLE) against important fish pathogens, which affect the commercial aquaculture throughout the world. NNLE showed species specific activity in inhibiting the growth of three virulent bacteria pathogenic to fish viz., Aeromonas hydrophila, Pseudomonas fluorescens, and Staphylococcus auras.

\section{Materials and Methods}

\section{Plant material}

Fresh, disease free Nelumbo nucifera leaves were collected during vegetative phase (MayJune, 2018) from Mansbal Lake, Safapora Ganderbal, Jammu \& Kashmir. The leaves were thoroughly washed with tap water to remove any debris and dirt. After chopping, the plant material was dried in hot air oven at $60^{\circ} \mathrm{C}$ for 12 hours (Arjun et al., 2012). The dried leaves were made into fine power by using a grinder (Philips H11645 750-watt), and the powder was subsequently sieved through a 20 mesh (0.74 mm gap size) and stored at $4^{\circ} \mathrm{C}$ until further use.

\section{Extract preparation}

10 grams of Nelumbo nucifera leaf powder was macerated first with $100 \mathrm{ml}$ of distilled water followed by $100 \mathrm{ml}$ of $75 \%$ ethanol for 36 hours with continuous starring. The suspension was filtered through Whatman no. 1 filter paper. The filtrate was dried in a rotary evaporator (Singla Scientific Glass Industries, India). Similar procedure was followed when acetone was used as solvent instead of ethanol. A separate crude extract of lotus leaf was prepared by using only water as solvent. The final yield of Nelumbo nucifera leaf extract (NNLE) was expressed in $\mathrm{mg} / \mathrm{gram}$ (table 2) based on dried leaf weight. The NNLE was stored at $4^{\circ} \mathrm{C}$ until further use.

\section{Methods of evaluating antioxidant properties}

\section{Estimation of DPPH scavenging}

Antioxidant activity of lotus crude extract was determined by following MacDonald et al., 2006 with slight modification. The lotus leaf extract samples with different concentrations were taken and then $2 \mathrm{ml}$ of $0.06 \mathrm{M}$ methanolic DPPH (procured from Sigma- 
Aldrich, USA) was added. After through mixing and incubating in dark for $30 \mathrm{~min}$ at room temperature, the radical scavenging activity was determined by measuring the optical density (OD) value at $517 \mathrm{~nm}$ using UV-Visible light spectrophotometer (Evolution 201, Thermo Scientific ${ }^{\mathrm{TM}}$ ) against the reagent blank. The control containing no lotus leaf extract was also run along with the samples.

\section{Estimation of total phenolic contents}

Total phenolic content in the crude leaf extract was estimated by the method of Singleton \& Rosy (1965). $30 \mu \mathrm{L}$ of lotus leaf was taken in a test tube and the volume was made up to $3 \mathrm{ml}$ with distilled water. $0.5 \mathrm{ml}$ of Folin-Ciocalteau reagent was added followed by $2 \mathrm{ml}$ of $20 \%$ of sodium carbonate after 3 min. The tubes were then placed in boiling water for 1 minute and the absorbance was taken at $650 \mathrm{~nm}$ against the reagent blank. Gallic acid was used as the standard and the standard curve of absorbance against different concentrations was prepared. The total phenolic content was expressed in $\mathrm{mg}$ phenols/100g sample.

\section{Bacterial strains}

All the three fish bacterial pathogens were procured from Microbial Type Culture Collection and Gene Bank (MTCC), CSIRInstitute of Microbial Technology, Chandigarh, India (Table1).

\section{Antimicrobial activity}

Minimum Inhibitory Concentration (MIC) of NNLE was determined by using disk diffusion method and broth micro-dilution methods as described by Klancnik et al., 2010and Irith et al., 2008 with slight modification. The bacterial strains were maintained in nutrient broth (sigma) under culture conditions at $37{ }^{\circ} \mathrm{C}$.

\section{Disk diffusion method}

For the disk diffusion assay (NARMS, 2002)1 $\mathrm{mL}$ of each bacterial suspension $\left(10^{4} \mathrm{CFU}\right.$ $\mathrm{mL}^{-1}$ ) was uniformly spread on a Miller Hinton agar in a petri dish. Five millimetre (diameter) discs prepared from Whatman no. 4 filter paper. Different concentrations of $250 \mu \mathrm{g} / \mathrm{ml}, \quad 125 \mu \mathrm{g} / \mathrm{ml}, \quad 62.5 \mu \mathrm{g} / \mathrm{ml}$, and $31.25 \mu \mathrm{g} / \mathrm{ml}$ of NNLE were prepared by dissolving the extract in DMSO. The discs incorporated with respective concentration of NNLE and were left to dry for 1 hour under sterile conditions and placed on cultured pathogenic bacteria on MHA plates incubated at $37^{\circ}$ C. Antibacterial activity as MIC was determined as the lowest concentration of plant extract, which produced an inhibition zone around a disk following the $24 \mathrm{~h}$ incubation (Valgas et al., 2007). Discs impregnated with sterile distilled water and DMSO served as negative controls, and a disk with an antibiotic (Chloramphenicol $25 \mathrm{mcg}$ procured from HiMedia) served as a positive control. Replicas at each concentration were performed.

\section{Broth micro-dilution method}

$10 \mu \mathrm{L}$ of each bacterial suspension $\left(10^{5}-10^{6}\right.$ $\mathrm{CFU} / \mathrm{mL}$ ) in nutrient broth was added to the wells of a sterile 96-well micro-titre plate already containing $190 \mu \mathrm{L}$ of two-fold serially diluted NNLE. The final volume in each well was $200 \mu \mathrm{L}$. Control wells were prepared with culture medium, bacterial suspension only, plant extracts only and DMSO in amounts corresponding to the highest quantity present. The contents of each well were mixed on a microplate shaker (Eppendorf, Hamburg Germany) at $900 \mathrm{rpm}$ for $1 \mathrm{~min}$ prior to incubation for $24 \mathrm{~h}$ in the cultivation conditions described above. The MIC was the lowest concentration where no viability was observed after $24 \mathrm{~h}$ based on metabolic activity (Mourey and Canillac, 2002). To indicate respiratory activity the presence of 
colour was determined after adding 10 $\mu \mathrm{L} /$ well of TTC (2,3,5- triphenyl tetrazoliumchloride, Sigma) dissolved in sterile water (TTC $20 \mathrm{mg} / \mathrm{mL}$ ) and incubated under appropriate cultivation conditions for $30 \mathrm{~min}$ in dark (Ellof, 1998). All measurements of MIC values were repeated in triplicate.

\section{Statistical analysis}

To validate the reproducibility of results, each assay was done in triplicate. One-way analysis of variance (ANOVA) using SPSS v. 20 was performed after the data ensured normal distribution. All analyses were performed considering a level of $95 \%$ of confidence $(P<0.05)$.

\section{Results and Discussion}

\section{DPPH (2，2-Diphenyl-1-picrylhydrazyl) radical scavenging method}

The DPPH radical has a deep purple colour which is reduced by antioxidant/reducing compound to the corresponding pale yellow hydrazine. The free radical scavenging capacity of the crude leaf extract with different concentrations was tested using the stable free radical DPPH. The ability of each concentration of extract to scavenge DPPH radical are represented as percentage inhibition (\%) (Table 3). The crude extract exhibited varying degrees of scavenging capacity depending on the concentration. All the concentrations of extract vary significantly $(p<0.05)$, except that there was no significant different in the scavenging capacity of $5.5 \mathrm{mg} / \mathrm{ml}$ and $7 \mathrm{mg} / \mathrm{ml}$ concentrations. The maximum concentration $(10 \mathrm{mg} / \mathrm{ml})$ of the extract showed the highest scavenging effect $(57.75 \%)$, whereas the lowest concentration $(0.5 \mathrm{mg} / \mathrm{ml})$ of the extract showed the least scavenging capacity $(9.30 \%)$.

\section{Total phenolic content}

The total phenolic contents of lotus leaf extract with different concentrations were significantly different $(p<0.05)$ (Table 3$)$. The phenolic contents exhibited similar trend as that of DPPH. Total phenolic compounds increased with the increasing concentration of lotus leaf extract.

\section{Antibacterial property}

Disc diffusion and broth micro-dilution methods showed bactericidal properties of lotus leaf extract. In disc diffusion test, MIC values of Nelumbo nucifera leaf extracts against the different bacterial strains were ranged from $31.25 \mathrm{ul} / \mathrm{ml}$ to $250 \mathrm{ul} / \mathrm{ml}$, as shown in table 4 . The maximum activity was against Aeromonas hydrphila with MIC value of $31.25 \mathrm{ul} / \mathrm{ml}$ using ethanol-water based solvent. The lowest inhibition of $1 \mathrm{~mm}$ was against Staphylococcus aureus using water as extraction solvent. In broth micro-dilution method, MIC values of lotus leaf extract for different fish pathogenic bacteria was 250 $\mathrm{ul} / \mathrm{ml}$ (Figure 1).

Table.1 Bacterial strains procured from MTCC CSIR-Institute of Microbial Technology, Chandigarh, India

\begin{tabular}{|l|l|l|}
\hline S. No. & Bacterial strain & MTCC collection acc. no. \\
\hline $\mathbf{1}$ & Staphylococcus aureus & 3103 \\
\hline $\mathbf{2}$ & $\begin{array}{l}\text { Pseudomonas } \\
\text { fluorescens }\end{array}$ & 103 \\
\hline $\mathbf{3}$ & Aeromonas hydrophila & 1739 \\
\hline
\end{tabular}


Table.2 Final yield of dried Nelumbo nucifera leaf powder

\begin{tabular}{|l|l|l|l|}
\hline & Aqueous & $\begin{array}{l}\text { Acetone- } \\
\text { Water }\end{array}$ & $\begin{array}{l}\text { Ethanol- } \\
\text { Water }\end{array}$ \\
\hline $\begin{array}{l}\text { Yield } \\
\text { (mg/gram) }\end{array}$ & 40 & 150 & 250 \\
\hline
\end{tabular}

Table.3 DPPH inhibition (\%) of crude lotus leaf extract at different concentration

\begin{tabular}{|l|l|l|}
\hline $\begin{array}{l}\text { Concentrations } \\
(\mathbf{m g} / \mathbf{m l})\end{array}$ & $\begin{array}{l}\text { DPPH (inhibition } \\
\mathbf{\%})\end{array}$ & $\begin{array}{l}\text { Phenolic } \\
(\mathbf{m g} / \mathbf{1 0 0 g}\end{array}$ \\
\hline $\mathbf{0 . 5 0}$ & $9.30^{\mathrm{a}} \pm 0.0$ & $13.75^{\mathrm{a}} \pm 0.01$ \\
\hline $\mathbf{1 . 2 5}$ & $17.08^{\mathrm{c}} \pm 0.0$ & $15.39^{\mathrm{b}} \pm 0.01$ \\
\hline $\mathbf{2 . 5 0}$ & $22.68^{\mathrm{d}} \pm 0.01$ & $18.51^{\mathrm{c}} \pm 0.02$ \\
\hline $\mathbf{4 . 0 0}$ & $33.15^{\mathrm{e}} \pm 0.0$ & $20.93^{\mathrm{d}} \pm 0.02$ \\
\hline $\mathbf{5 . 0 0}$ & $38.56^{\mathrm{f}} \pm 0.0$ & $22.53^{\mathrm{e}} \pm 0.015$ \\
\hline $\mathbf{5 . 5 0}$ & $41.85^{\mathrm{g}} \pm 0.0$ & $24.96^{\mathrm{f}} \pm 0.02$ \\
\hline $\mathbf{7 . 0}$ & $42.47^{\mathrm{g}} \pm 1.33$ & $25.08^{\mathrm{t}} \pm .0 .005$ \\
\hline $\mathbf{8 . 5 0}$ & $48.01^{\mathrm{h}} \pm 0.0$ & $28.60^{\mathrm{h}} \pm 0.005$ \\
\hline $\mathbf{1 0 . 0}$ & $57.75^{\mathrm{1}} \pm 0.0$ & $37.76^{\mathrm{t}} \pm 0.01$ \\
\hline
\end{tabular}

Mean values in a row with different superscript differ significantly $(P<0.05)$. Data expressed as mean \pm S.D. $n=3$

Table.4 MIC of Nelumbo nucifera leaf extract by disc diffusion method

\begin{tabular}{|c|c|c|c|c|}
\hline \multirow{2}{*}{$\begin{array}{l}\text { Extraction } \\
\text { Medium }\end{array}$} & \multirow{2}{*}{$\begin{array}{l}\text { Concentration } \\
\text { Crude Extract }\end{array}$} & \multicolumn{3}{|c|}{ Zone of inhibition (mm) } \\
\hline & & $\begin{array}{l}\text { Staphylococcus } \\
\text { aureus }\end{array}$ & $\begin{array}{l}\text { Pseudomonas } \\
\text { fluorescens }\end{array}$ & $\begin{array}{l}\text { Aeromonas } \\
\text { hydrophila }\end{array}$ \\
\hline \multirow[t]{4}{*}{ Aqueous } & $250 \mu \mathrm{g} / \mathrm{ml}$ & $3 \pm 0.0^{\mathrm{a}}$ & $2 \pm 0.1^{\mathrm{a}}$ & $4 \pm 0.0^{\mathrm{a}}$ \\
\hline & $125 \mu \mathrm{g} / \mathrm{ml}$ & $1 \pm 0.1^{b}$ & NI & $1 \pm 0.0^{\mathrm{b}}$ \\
\hline & $62.5 \mu \mathrm{g} / \mathrm{ml}$ & NI & NI & NI \\
\hline & $31.25 \mu \mathrm{g} / \mathrm{ml}$ & NI & NI & NI \\
\hline \multirow{4}{*}{$\begin{array}{l}\text { Acetone- } \\
\text { Water }\end{array}$} & $250 \mu \mathrm{g} / \mathrm{ml}$ & $6 \pm 0.1^{\mathrm{e}}$ & $7 \pm 0.1^{\mathrm{e}}$ & $9 \pm 0.21^{\mathrm{e}}$ \\
\hline & $125 \mu \mathrm{g} / \mathrm{ml}$ & $3 \pm 0.11^{\mathrm{f}}$ & $5 \pm 0.0^{f}$ & $7 \pm 0.1^{f}$ \\
\hline & $62.5 \mu \mathrm{g} / \mathrm{ml}$ & $1 \pm 0.0^{\mathrm{g}}$ & $2 \pm 0.0^{\mathrm{g}}$ & $4 \pm 0.0^{\mathrm{g}}$ \\
\hline & $31.25 \mu \mathrm{g} / \mathrm{ml}$ & NI & NI & $1 \pm 0.0^{\mathrm{h}}$ \\
\hline \multirow{4}{*}{$\begin{array}{l}\text { Ethanol- } \\
\text { Water }\end{array}$} & $250 \mu \mathrm{g} / \mathrm{ml}$ & $10 \pm 1.05^{\mathrm{i}}$ & $11 \pm 0.1^{\mathrm{i}}$ & $13 \pm 2.01^{i}$ \\
\hline & $125 \mu \mathrm{g} / \mathrm{ml}$ & $9.9 \pm 0.2^{i}$ & $8 \pm 0.0^{1}$ & $8 \pm 0.12^{i}$ \\
\hline & $62.5 \mu \mathrm{g} / \mathrm{ml}$ & $5 \pm 0.1^{j}$ & $6 \pm 0.14^{j}$ & $5 \pm 0.0^{\top}$ \\
\hline & $31.25 \mu \mathrm{g} / \mathrm{ml}$ & $4.3 \pm 0.11^{\mathrm{j}}$ & $3 \pm 0.0^{\mathrm{k}}$ & $4 \pm 0.11^{j}$ \\
\hline
\end{tabular}

Mean values in a row with different superscript differ significantly $(P<0.05)$. Data expressed as mean \pm S.D. $\mathrm{n}=3$, NI means no inhibition 
Fig.1 Minimum inhibition concentration of crude lotus leaf extract (NNLE) against different fish pathogenic bacteria using broth micro-dilution method. Rows (from top): 1-Aeromemas hydrophila, 2-Pseudomonas fluorescens, 3-Staphylococcus aureus. Columns (from left): 1Positive control, 2-500 ul/ml, 3- $250 \mathrm{ul} / \mathrm{ml}, 4-125 \mathrm{ul} / \mathrm{ml}, 5-62.5 \mathrm{ul} / \mathrm{ml}, 6-31.25 \mathrm{ul} / \mathrm{ml}, 7-15.62$ $\mathrm{ul} / \mathrm{ml}, 8-7.81 \mathrm{ul} / \mathrm{ml}, 9-3.90 \mathrm{ul} / \mathrm{ml}, 10-1.95 \mathrm{ul} / \mathrm{ml}, 11-0.97 \mathrm{ul} / \mathrm{ml}, 12-$ Negative control

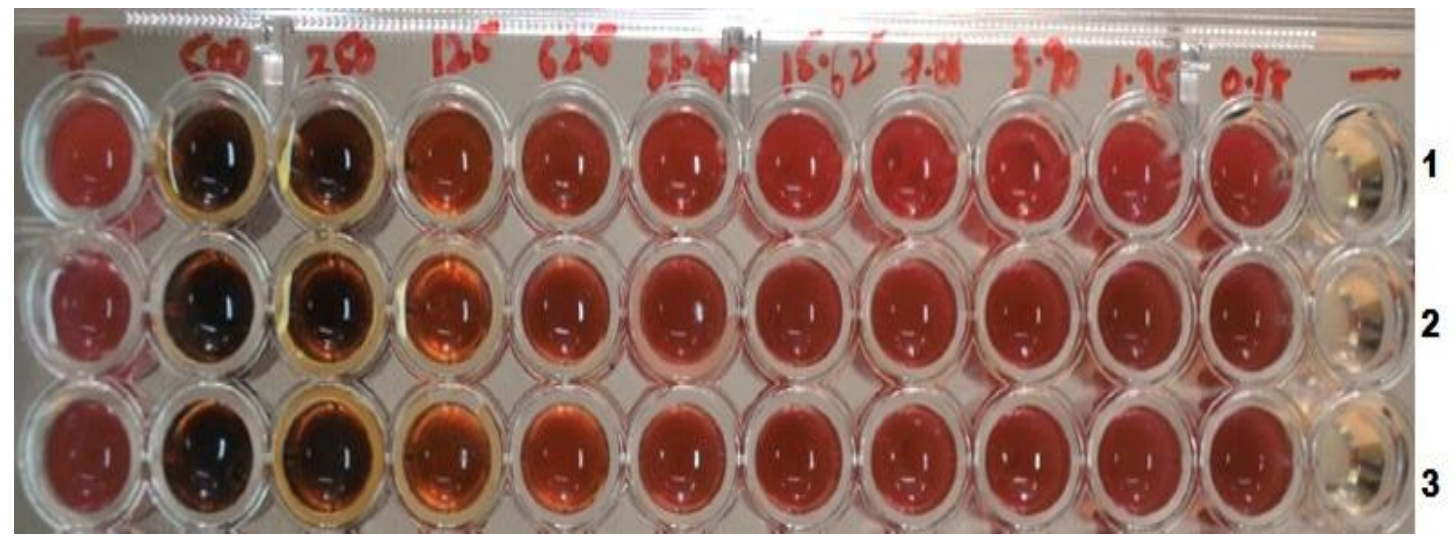

Several methods are available for the extraction of antioxidants from the plant materials (organic solvent extraction, aqueous extraction etc). The effectiveness of the extraction depends upon the method employed and the species used (Balouiri et al., 2016). The results of determining the antioxidant activity can be highly variable which cannot be explained by on single method. Thus, in the present study, aqueous extraction was carried out and two different methods, each having different mechanisms of antioxidant action, were employed to check the antioxidant property of the extract.

DPPH is a free radical compound that has been widely used to determine the free radical scavenging capacity of the various samples. The advantage of using DPPH assay is its stability of free radical and speed (Bozin et al., 2007). The free radical scavenging activity of the lotus leaf extract was expressed as percentage inhibition. The results showed that the higher concentration of the extract had higher radical scavenging effect (52.04 \pm 0.00 ). In the present study, it was observed that the greater phenolic contents exhibited increased DPPH scavenging activity. The possible reason for this could be the increase in concentration of phenolic compounds present in the plant extract as its concentration was increased. According to Li et al., (2008) boiling could be better choice for obtaining antioxidant rich extracts from the plants, which is in agreement with the present study.

The total phenolic content of the plant extract is a good indicator of the total antioxidant power of the extract (Fernandes et al., 2016). Considering this, the total phenolic contents of the extract was studied by Folin-Ciocalteu method, which showed an increasing trend between the concentration of the extract and the antioxidant activity parameters. The highest concentration of the lotus leaf extract $(10 \mathrm{mg} / \mathrm{ml})$ showed the presence of highest amount of total phenols $34.66 \pm 0.011 \mathrm{mg} / 100 \mathrm{~g}$. Li et al., (2008) observed a high correlation between the antioxidant capacities obtained from Ferric Reducing Antioxidant Power (FRAP) assay and the phenolic contents of 45 different plants $\left(r^{2}=0.8672\right)$. Moreover many studies have reported that the phenolic compounds are responsible the antioxidant 
activity (Liu et al., 2008; Rempe et al., 2017; Sharifi- Rad et al., 2018). Phenolic compounds (flavonoids for instance) have redox properties, which allow them to act as antioxidants. As their free radical scavenging ability is facilitated by their hydroxyl groups, the total phenolic concentration could be used as a basis for rapid screening of antioxidant activity. Flavonoids, including flavones, flavanols and condensed tannins, are plant secondary metabolites, the antioxidant activity of which depends on the presence of free $\mathrm{OH}$ groups, especially 3-OH. Plant flavonoids show both in vitro and in vivo antioxidant activity (Geeta, et al., 2003; Shimoi, et al., 1996). The crude lotus leaf extract was observed to have good total phenolic contents which indicate its potential as a natural antioxidant to prevent oxidative damage in fish.

Chen et al., (2015), have evaluated the antibacterial activity of Nulembo nucifera leaf extract. They have reported lotus leaf extract as potential antibacterial agent against E. coli, $S$. typhimurium, $S$. aureus and B. subtilis. The present in vitro results for antibacterial study are in agreement with the findings of (Dubey et al., 2012) who reported that ethanol extract of most plants had effective antimicrobial activity against all the isolated multidrug resistant bacteria. Furthermore, the extracts (ethanol and acetone) of leaves showed significant activity against Gram-negative bacteria and Gram-positive bacteria. According to some reports the presence of secondary metabolites in plants viz., alkaloids (Gurudeeban et al., 2013; Budeyri et al., 2012) and flavones (Islam et al., 2002; Li et al., 2012) have significant antimicrobial activities. This may explain the efficiency of ethanol-extract for antimicrobial activity. It indicates that the alkaloids and flavones present in plant extract might have synergistic effect against bacterial growth. While some alkaloids such as colchicine, aconitine, scopolamine, strychnine are toxic even they are isolated from natural product, there is no reports about the toxicological evaluation of lotus leaves alkaloids. It is essential to perform toxicological evaluation of lotus leaves alkaloids in the future for its safe use as animal or fish feed additive.

In conclusion, the antibacterial activity of the lotus extract could be related to the presence of bioactive components like alkaloids and flavonoids. Results of present study suggest that the lotus leaf extract possess significant antioxidant activity and antibacterial compounds, which may be used as feed additives and therapeutics in fish nutrition and aquaculture industry. The antibacterial mechanism of lotus leaf extract is unclear and needs further research.

\section{Acknowledgment}

Authors are thankful to the Prof. A. M. Ganai and other technical staff of Div. of Animal Nutrition, FVSc \& AH, SKUASTK for their support. Thanks are also due to Mr. Ghulam Rasool Wani, FCLA Div. of Parasitology FVSc \& AH for his help during collection of lotus leaves from Manasbal Lake.

\section{References}

Antunes, R.M.P., Lima, E.O., Pereira, M.S.V., Camara, C.A., Arruda, T.A., Catão, R.M.R., Barbosa, T.P., Nunes, X.P., Dias, C.S., Silva, T.M.S. (2006). Atividade antimicrobiana "in vitro" e determinação da concentração inibitória mínima (CIM) de fitoconstituintes e produtos sintéticos sobre bactérias e fungos leveduriforme. Rev. Bras. Farmacogn., 16, 517-524.

Arjun, P., S. Mohana Priya, PS Saranya Sivan, M. Krishnamoorthy, and K. Balasubramanian. (2012). Antioxidant and antimicrobial activity of Nelumbo 
nucifera Gaertn. leaf extracts." J. Acad. Indus. Res 1, no. 1:15-19.

Austin, B. and Austin, D.A., 2012. Bacterial fish pathogens (p. 652). Heidelberg, Germany: Springer.

Balouiri, Mounyr, Moulay Sadiki, and Saad Koraichi Ibnsouda. "Methods for in vitro evaluating antimicrobial activity: A review." Journal of pharmaceutical analysis 6.2 (2016): 71-79.

Bozin, B., N. Mimica-Dukic, I. Samojlik and E.A. Jovin, 2007. Antimicrobial and antioxidant properties of rosemary and sage (Rosmarinus officinalis L. and Salvia officinalis L., Lamiaceae) essential oils. J. Agric. Food Chem., 55: 7879-7885.

Budeyri, N., D. Kazan, and B. S. Akbulut. (2012). Investigation of the antimicrobial effect of an alkaloid from: p27-48 papaver rhoeas: p2748k: p27-48." The Febs Journal 279: 552.

Bullock GL, 1966. Precipitins and agglutinin reaction of aeromonads isolated from fish and other sources. Bulletin de l'Office International des Epizooties, 65:805-824.

Bullock, G. L. (1964). Pseudomonadales as fish pathogens. Developments in Industrial Microbiology 5: 101-108.

Chen, Xiaotian, et al., (2015). Antibacterial activity of lotus leaves (Nelumbo nucifera) against food-borne pathogens." American Journal of Biochemistry \& Biotechnology 11.1:11.

Cowan, M.M. (1999). Plant products as antimicrobial agents. Clin. Microbiol. Rev., 12, 564-582.

Dubey, Debasmita, et al., (2012). Antimicrobial activity of medicinal plants used by aborigines of Kalahandi, Orissa, India against multidrug resistant bacteria." Asian pacific journal of Tropical biomedicine 2.2: S846-S854.

Egusa S, 1978. Sakanano Kansensho (Infectious Diseases of Fish). Koseisha Koseikaku, Tokyo, Pp. 225228.

Ellof, J.N., 1998. A sensitive and quick microplate method to determine the minimal inhibitory concentration of plant extracts for bacteria. Planta Med. 64, 711-713.

Fernandes, R. P. P., et al., "Evaluation of antioxidant capacity of 13 plant extracts by three different methods: cluster analyses applied for selection of the natural extracts with higher antioxidant capacity to replace synthetic antioxidant in lamb burgers." Journal of food science and technology 53.1 (2016): 451-460.

Figueiredo, H.C.P., Carneiro, D.O., Faria, F.C., Costa, G.M. (2006). Streptococcus agalactiae associado à meningoencefalite e infecção sistêmica em tilápia-do-Nilo (Oreochromis niloticus) no Brasil. Arq. Bras. Med. Vet. Zootec., 58, 678680.

Gurudeeban, S., T. Ramanathan, and K. Satyavani. "Antimicrobial and radical scavenging effects of alkaloid extracts from Rhizophora mucronata." Pharmaceutical Chemistry Journal 49.1 (2015): 34-37.

Hatha, M., Vivekanandhan, A.A., Joice, G.J. (2005). Christol. Antibiotic resistance pattern of motile aeromonads from farm raised fresh water fish. Int. J. Food Microbiol., 98, 131-134.

Hazen TC; Fliermans CB; Hirsch RP; Esch GW, 1978. Prevalence and distribution of Aeromonas hydrophila in the United States. Applied and Environmental Microbiology, 36:731738.

Irith Wiegand, Kai Hilpert and Robert E W Hancock, (2008). Agar and broth 
dilution methods to determine the minimal inhibitory concentration (MIC) of antimicrobial substances, Nature Protocols 3, $163-175$. doi:10.1038/nprot.2007.521

Islam Nazrul, S. K., et al., (2002). Screening of eight alkaloids and ten flavonoids isolated from four species of the genus Boronia (Rutaceae) for antimicrobial activities against seventeen clinical microbial strains." Phytotherapy Research: An International Journal Devoted to Pharmacological and Toxicological Evaluation of Natural Product Derivatives 16.7: 672-674.

K. Shimoi, S. Masuda, B. Shen, M. Furugori, N. Kinze, (1996). Radio-protective effects of antioxidative plant flavonoids in mice, Mutat. Res. Fund. Mol. 350:153-161.

Khardori N; Fainstein V, 1988. Aeromonas and Plesiomonas as etiological agents. Annual Review of Microbiology, 42:395-419.

Klančnik, Anja, Saša Piskernik, Barbara Jeršek, and Sonja Smole Možina. (2010). Evaluation of diffusion and dilution methods to determine the antibacterial activity of plant extracts." Journal of microbiological methods 81, no. 2: 121-126.

Li, B., Lu, F., Wei, X., and Zhao, R. 2008. Fucoidan: structure and bioactivity. Molecules, 13: 1671-1695.

$\mathrm{Li}$, Ke, et al., (2012). Anticomplement and antimicrobial activities of flavonoids from Entada phaseoloides." Natural product communications 7.7:867-871.

Li, W., Cheng, K., and Chen, F., 2008. Antioxidant properties in vitro and total phenolic contents in methanol extracts from medicinal plants. Food Sci. Technol., 41: 385-390

Lin, Bin, Shangwu Chen, Zhen Cao, Yiqun Lin, Dunzhou Mo, Haibo Zhang, Juda Gu, Meiling Dong, Zehuan Liu, and
Anlong Xu. (2007). Acute phase response in zebrafish upon Aeromonas salmonicida and Staphylococcus aureus infection: striking similarities and obvious differences with mammals." Molecular immunology 44, no. 4:295-301.

Liu, H., Qiu, N., Ding, H. and Yaro, R. 2008. Polyphenol contents and and antioxidant capacity of 68 Chinese herbals suitable for medical or food uses. Food Res. Int., 41: 363-30.

MacDonald-Wicks, Lesley K., Lisa G. Wood, and Manohar L. Garg. "Methodology for the determination of biological antioxidant capacity in vitro: a review." Journal of the Science of Food and Agriculture 86, no. 13 (2006): 2046-2056.

Mehta, N. R., Patel, E. P., Patani, P. V., and Shah, B. (2013). Nelumbo Nucifera (Lotus): A Review on Ethanobotany Phytochemistry and Pharmacology. Indian Journal of Pharmaceutical and Biological Research, (4):152-167 Ono, Y., Hattori, E., Fukaya, Y., Imai, S., and Ohizumi, Y. (2006). Antiobesity effect of Nelumbo nucifera leaves extract in mice and rats. Journal of Ethnopharmacology, 106 (2), 238244.

Ling, Z. Q., Xie, B. J., and Yang, E. L. (2005). Isolation, characterization, and determination of antioxidative activity of oligomeric procyanidins from the seedpod of Nelumbo nucifera Gaertn. Journal of agricultural and food chemistry, 53(7), 2441-2445.

Liu, W., Yi, D. D., Guo, J. L., Xiang, Z. X., Deng, L. F., \& He, L. (2015). Nuciferine, extracted from Nelumbo nucifera Gaertn, inhibits tumorpromoting effect of nicotine involving Wnt/ $\beta$-catenin signaling in non-small cell lung cancer. Journal of Ethnopharmacology, 165, 83-93. 
Mourey, A., Canillac, N., 2002. Anti-Listeria monocytogenes activity of essential oils components of conifers. Food Control 13, 289-292. NARMSNational Antimicrobial Resistance Monitoring System, 2002. Enteric Bacteria. CDC, USA. Pressley, Meagan E., Peter E. Phelan III, P. Eckhard Witten, Mark T. Mellon, and Carol H. Kim. (2005). Pathogenesis and inflammatory response to Edwardsiella tarda infection in the zebrafish." Developmental \& Comparative Immunology 29, no. 6: 501-513.

Rempe, Caroline S., et al., (2017). The potential of systems biology to discover antibacterial mechanisms of plant phenolics. Frontiers in microbiology 8: 422.

Sayre J. Propagation protocol for American Lotus (Nelumbo lutea Willd.) Native plants Journal 2004, 1:14- 17.

Schäperclaus W; Kulow H; Schreckenbach K, 1992. Infectious abdominal dropsy. In: Schäperclaus W, ed. Fish Diseases, Vol. 1. Berlin: Akademie-Verlag, 401458.

S. Geetha, M. Sai-Ram, S.S. Mongia, V. Singh, G. Ilavazha-gan, et al., (2003). Evaluation of antioxidant activity of leaf extract of sea buckthorn (Hippophae rhamnoides L.) on chromium (VI) induced oxidative stress in albino rats, J. Ethnopharmacol. 87: 247-251.

Serrano, P.H. (2005). Responsible use of antibiotics in aquaculture. In: Food and Agriculture Organization (FAO) Fisheries Technical Paper, 469, Roma, $97 \mathrm{p}$.

Sharifi-Rad, Mehdi, et al., "Echinacea plants as antioxidant and antibacterial agents: From traditional medicine to biotechnological applications." Phytotherapy Research (2018).

Sheikh, S. A. (2014). Ethno-medicinal uses and pharmacological activities of lotus (Nelumbo nucifera). Journal of Medicinal Plants Research, 2 (2), 4246.Al-Harbi, Ahmed H. "First isolation of Streptococcus sp. from hybrid tilapia (Oreochromis niloticus, $O$. aureus) in Saudi Arabia." Aquaculture 128.3-4 (1994): 195-201.

Singleton, Vernon L., and Joseph A. Rossi. "Colorimetry of total phenolics with phosphomolybdic-phosphotungstic acid reagents." American journal of Enology and Viticulture 16, no. 3 (1965): 144-158.

Valgas, C., de Souza, S.M., Smânia, E.F.A., Smânia Jr., A., 2007. Screening methods to determine antibacterial activity of natural products. Braz. J. Microbiol. 38, 369-380.

Yanong, R.P.E., Francis-Floyd, R. (2006). Streptococcal infections of fish. The institute of food and agricultural sciences. Circular. 57, 1-6.

Yu, B.H., Kaur, R., Lim, S., Wang, X.H., Leung, K.Y. (2007). Characterization of extracellular proteins produced by Aeromonas hydrophila AH-1. Proteomics. 7, 436-449.

\section{How to cite this article:}

Mudasir Maqsood Hakim, Nazir Ahmad Ganai, Syed Mudasir Ahmad, Oyas Ahmad Asimi, Tariq Raja, Feroz Ahmad Shah, Jalal-ul-Din Parrah and Riaz Ahmad Shah. 2019. Evaluation of In vitro Antioxidant Activity of Nelumbo nucifera Leaf Extract and its Potential Application as Antibacterial Agent against Fish Pathogens. Int.J.Curr.Microbiol.App.Sci. 8(06): 379-389. doi: https://doi.org/10.20546/ijcmas.2019.806.043 